\title{
Analisis Risiko Kecelakaan Kerja Pada Proyek Spazio Tower II Surabaya Menggunakan Metode Bowtie
}

\author{
Winda Bintang Veroza dan Cahyono Bintang Nurcahyo \\ Departemen Teknik Sipil, Fakultas Teknik Sipil dan Perencanaan, Institut Teknologi Sepuluh Nopember (ITS) \\ e-mail: bintang@ce.its.ac.id
}

\begin{abstract}
Abstrak-Risiko didefinisikan sebagai suatu kemungkinan dari suatu kejadian yang akan mempengaruhi suatu tujuan. Proyek konstruksi Spazio Tower II merupakan bangunan tingkat tinggi yang memiliki potensi risiko dalam hal kecelakaan kerja. Penulisan penelitian ini bertujuan untuk mengetahui risiko dominan, dan mengetahui faktor penyebab dan dampak dari risiko dominan. Data eksisting yang diperoleh untuk mengetahui risiko kecelakaan kerja yang paling dominan dimulai dengan penilaian risiko yaitu perhitungan probability dan impact, menggunakan Risk Management Standard AS/NZ 4360:1999. Metode yang digunakan untuk mengidentifikasi sumber penyebab dan dampak terhadap risiko kecelakaan kerja menggunakan Metode Bowtie. Hasil dari penelitian ini adalah mengetahui risiko kecelakaan kerja yang paling dominan yaitu, alat berat tergelincir ke lubang galian pada pekerjaan galian tanah, pekerja jatuh dari ketinggian akibat saling gondola putus pada pekerjaan pengecatan di ketinggian, dan pekerja tertimpa konstruksi baja akibat sling Tower Crane(TC) putus pada pekerjaan struktur atap baja. Penyebab dari risiko kecelakaan kerja yang dominan berdasarkan Metode Bowtie adalah kondisi fisik operator kurang baik, metode penggalian, hujan/gerimis, keadaan mesin/alat berat kurang baik, keausan pada kawat sling gondola, cuaca ekstrem, kondisi kesehatan operator gondola, metode pengoperasian gondola, keausan dan korosi pada kawat sling TC, cuaca ekstrem, kondisi kesehatan operator TC, metode pengoperasian TC, dan berat beban konstruksi baja. Dampak dari risiko kecelakaan kerja yang dominan berdasarkan Metode Bowtie adalah operator mengalami luka memar akibat benturan saat tergelincir, pekerja mengalami kematian akibat jatuh dari ketinggian, gondola mengalami kerusakan akibat jatuh dari ketinggian, dan pekerja mengalami kematian akibat tertimpa konstruksi atap baja. Faktor eskalasi dari risiko kecelakaan kerja yang dominan adalah lupa/menolak menggunakan Alat Pelindung Diri (APD), tidak adanya penambahan Safety Rope, dan kurangnya komunikasi.
\end{abstract}

Kata Kunci_Analisis Risiko, Kecelakaan Kerja, Metode Bowtie.

\section{PENDAHULUAN}

$\mathrm{P}$ EMBANGUNAN proyek gedung tinggi merupakan salah satu pembangunan yang memiliki potensi risiko dalam hal kecelakaan kerja. Penggunaan metode pelaksanaan yang tidak akurat serta kurang teliti dapat mengakibatkan risiko kecelakaan kerja.

Metode Bowtie berkembang dari industri minyak dan gas bumi pada sekitar akhir 1970-an untuk manajemen K3 (kesehatan\&keselamatan). Royal Dutch Shell adalah perusahaan besar yang pertama diketahui menerapkan analisis ini dalam praktik bisnis mereka dalam sistem yang disebut THESIS (The Health, Environment, Safety Information System) [1].

Spazio Tower II Surabaya di J1. Mayjend Yono Soewoyo milik Intiland ini merupakan gedung perkantoran strata title yang menjadi bagian dari pengembang Graha. Proyek Spazio Tower II terdiri dari 29 lantai, dengan luas bangunan mencapai \pm 77.834 meter persegi. Dari total lantai tersebut, terdapat Area Parkir (Basement) 5 Lantai, Area Publik 2 Lantai, Area Kantor 12 lantai, Hotel 5 Lantai, dan Area Utilitas 2 Lantai

Tujuan dari penelitian ini adalah untuk menerapkan Metode Bowtie dalam proses pembangunan Proyek Spazio Tower II Surabaya, sehingga dapat menentukan Variabel risiko dominan termasuk Probability, Impact, dan Faktor Eskalasi respon terhadap risiko yang mungkin terjadi.

\section{METODOLOGI PENELITIAN}

\section{A. Variabel Penelitian}

Variabel penelitian awal didapatkan dari studi literatur, observasi di lapangan,dan wawancaradengan kontraktor, yang kemudian akan disusun dalam kuesioner untuk melaksanakan survei pendahuluan dan survei utama kepada responden.

\section{B. Responden}

Pengambilan data dilakukan kepada 10 responden terpilih yang mempunyai kompetensi terhadap topik penelitian, yaitu:
a) Site Manager, sebanyak 1 orang.
b) Staff Teknik, sebanyak 4 orang.
c) Drafter, sebanyak 1 orang
d) Quality Control, sebanyak 3 orang
e) Unit $K 3$, sebanyak 1 orang

\section{Survei Kuesioner}

Survei dilakukan untuk mengidentifikasi variabel risiko kecelakaan kerja, mengetahui probability, dan mengetahui impact dari risiko kecelakaan kerja.

Tahapan dalam penelitian ini dapat dilihat pada Gambar 1 berikut.

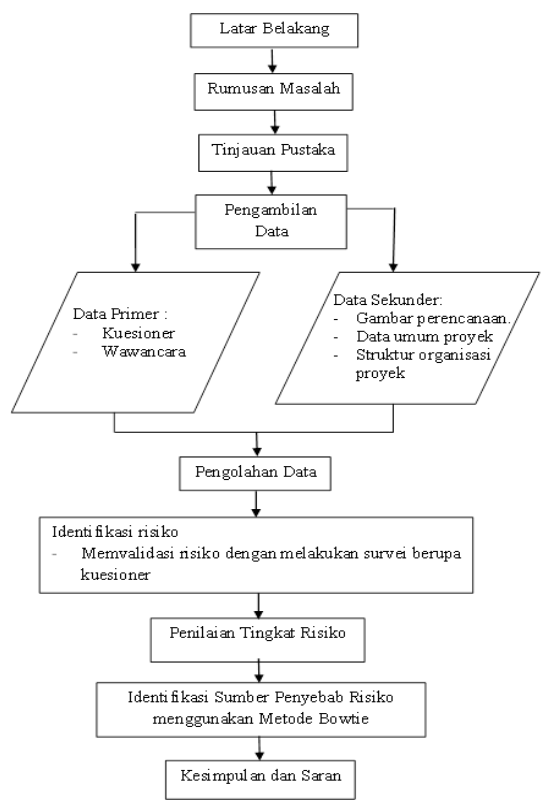


Gambar 1. Diagram Alir Penelitian

\section{ANALISIS DAN PEMBAHASAN}

\section{A. Identifikasi Risiko Kecelakaan}

Langkah ini dilakukan melalui studi literatur, observasi di lapangan,dan wawancara dengan kontraktor yang kemudian disusun dalam bentuk kuisioner untuk melakukan survei pendahuluan.

\section{B. Penilaian Risiko}

Langkah ini dilakukan dengan tahap sebagai berikut.

1. Penyebaran survei utama hasil identifikasi risiko awal kepada responden terpilih, untuk menentukan probability yang terjadi dan impact yang ditimbulkan dari risiko tersebut,

2. Menentukan risiko dominan yaitu variabel risiko yang tergolong Very High risk pada hasil pemetaan pada matriks risiko.

Penilaian risiko dilakukan dengan menggunakan tingkat probability dan impact [2] seperti yang dijelaskan pada Tabel 1 dan tabel 2 berikut.

Tabel 1.

Tingkat Probability

\begin{tabular}{ccc}
\hline \hline Level & Deskripsi & Uraian \\
\hline 5 & Almost Certain & Dapat terjadi setiap saat \\
4 & Likely & Sering \\
3 & Possible & Dapat terjadi sekali-sekali \\
2 & Unlikely & Jarang \\
1 & Rare & Hampir tidak pernah, sangat \\
& & jarang terjadi \\
\hline \hline
\end{tabular}

Tabel 2.

Tingkat Impact

\begin{tabular}{ccl}
\hline \hline $\begin{array}{c}\text { Tingk } \\
\text { at Risiko }\end{array}$ & Deskripsi & \multicolumn{1}{c}{ Dampak } \\
\hline 1 & $\begin{array}{c}\text { Tidak } \\
\text { signifikan }\end{array}$ & $\begin{array}{l}\text { Tidak ada cedera, kerugian finansial } \\
\text { sedikit } \\
\text { a. Cedera ringan misal luka lecet } \\
\text { b. Kerugian finansial sedang } \\
\text { a. Cedera sedang, perlu penanganan medis } \\
\text { b. Kerugian finansial besar } \\
\text { c. Setiap kasus yang memperpanjang }\end{array}$ \\
& Moderat & $\begin{array}{l}\text { Merawatan } \\
\text { a. Cedera luas/berat }>\text { 1 orang } \\
\text { b. Kerugian besar, gangguan produksi }\end{array}$ \\
& Major & $\begin{array}{l}\text { Fatal }>\text { 1 orang, kerugian sangat besar dan } \\
\text { dampak sangat luas, terhentinya seluruh } \\
\text { kegiatan }\end{array}$ \\
\hline \hline
\end{tabular}

Data yang diperoleh dari kuesioner terhadap 10 responden, kemudian diolah untuk mendapatkan nilai probability index dan impacts index dengan menggunakan rumus Index Analysis [3].

$$
I=\frac{\sum_{i=0}^{4} a_{i} \cdot x_{i}}{4 \sum_{i=0}^{4} x_{i}} x 100 \%
$$

Berikut adalah contoh perhitungan probability index pada variabel risiko 1e (alat berat tergelincir ke lubang galian) untuk 1 responden menjawab 2 (Unlikely), 2 responden menjawab 3 (Possible), 7 responden menjawab 4 (Likely).

$$
P I=\frac{\sum_{1}^{4}(0 \times 0)+(1 \times 0)+(2 \times 1)+(3 \times 2)+(4 \times 7)}{4 \sum_{i=1}^{4}(10)} \times 100 \%
$$

Berikut adalah contoh perhitungan impact indexpada variabel risiko 1e (alat berat tergelincir ke lubang galian) untuk 1 responden menjawab 2 (Minor), 3 responden menjawab 3 (Moderat), 6 responden menjawab 4 (Major)

$$
\text { II }-\frac{\sum_{a}^{4}(0 \times 0)+(1 \times 0)+(2 \times 1)+(3 \times 3)+(4 \times 6)}{4 \sum_{0}^{4}(10)} \times 100 \%
$$

II $-88 \%$

Nilai probability index dan impact index yang didapatkan tersebut masih dalam bentuk prosentase, sehingga perlu untuk diklasifikasikan kembali melalui indeks [4].

Klasifikasi dari skala penilaian pada indeks tersebut adalah sebagai berikut.
Skala $1 \quad: 0 \% \quad<\mathrm{I} \leq 20 \%$
Skala $2 \quad: 20 \%<\mathrm{I} \leq 40 \%$
Skala $3 \quad: 40 \%<\mathrm{I} \leq 60 \%$
Skala $4 \quad: 60 \%<\mathrm{I} \leq 80 \%$
Skala $5 \quad: 80 \%<\mathrm{I} \leq 100 \%$

Nilai PI sebesar $90 \%$ adalah masuk dalam extremely effective karena berada dalam range $80 \%<\mathrm{SI} \leq 100 \%$, sedangkan nilai II sebesar $88 \%$ masuk dalam extremely effective karena masuk dalam range $80 \%<\mathrm{SI} \leq 100 \%$.

Tabel 3 dan tabel 4 secara berturut-turut menunjukkan contoh dari rekap kuesioner terhadap 10 responden, penilaian probability index, dan penilaian impact index secara detail dan lengkap untuk variabel risiko 1e (alat berat tergelincir ke lubang galian).

\begin{tabular}{|c|c|c|c|c|c|c|c|c|}
\hline \multirow{2}{*}{$\begin{array}{c}\text { Item } \\
\text { Pekerjaa } \\
\text { n }\end{array}$} & \multirow{2}{*}{$\begin{array}{c}\text { Variabel } \\
\text { Risiko }\end{array}$} & \multicolumn{5}{|c|}{ Tingkat Probability } & \multicolumn{2}{|r|}{ PI } \\
\hline & & 1 & 2 & 3 & 4 & 5 & $\%$ & Rank \\
\hline $\begin{array}{c}\text { Pekerjaan } \\
\text { Galian } \\
\text { tanah }\end{array}$ & $\begin{array}{l}\text { 1e. Alat } \\
\text { berat } \\
\text { tergelinc } \\
\text { ir ke } \\
\text { lubang } \\
\text { galian }\end{array}$ & 0 & 0 & 1 & 2 & 7 & $0^{9}$ & $\begin{array}{c}5 \\
\text { (almost } \\
\text { certain) }\end{array}$ \\
\hline
\end{tabular}

Tabel 3.

Penilaian Probability Index

\begin{tabular}{|c|c|c|c|c|c|c|c|c|}
\hline \multirow{2}{*}{$\begin{array}{c}\text { Item } \\
\text { Pekerjaan }\end{array}$} & \multirow{2}{*}{$\begin{array}{l}\text { Variabe } \\
1 \text { Risiko }\end{array}$} & \multicolumn{5}{|c|}{ Tingkat Impact } & \multicolumn{2}{|r|}{ II } \\
\hline & & 1 & 2 & 3 & 4 & 5 & $\%$ & Rank \\
\hline $\begin{array}{l}\text { Pekerja } \\
\text { an Galian } \\
\text { tanah }\end{array}$ & $\begin{array}{l}\quad \text { 1e. Alat } \\
\text { berat } \\
\text { tergelincir } \\
\text { ke lubang } \\
\text { galian }\end{array}$ & 0 & 0 & 1 & 3 & 6 & $8^{8}$ & $\begin{array}{c}5 \\
\text { (extreme) }\end{array}$ \\
\hline
\end{tabular}

Tabel 4.

Penilaian Impact Index

Hasil penilaian Probability Index dan Impact Index tersebut kemudian dipetakan pada matriks risiko [3], yang contohnya dapat dilihat pada tabel 5 berikut ini.

\begin{tabular}{|c|c|c|c|c|c|c|}
\hline \multirow[b]{2}{*}{ Probability } & & \multicolumn{5}{|c|}{ Impact } \\
\hline & & $\begin{array}{c}\text { Insig } \\
- \\
\text { nific }\end{array}$ & Min & $\begin{array}{l}\text { Mod } \\
e-\end{array}$ & Majo & Extr \\
\hline$R a$ & 7 & $T$ & $T$ & $T$ & $T$ & 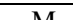 \\
\hline Unlikely & 2 & $\mathrm{~L}$ & $\mathrm{~L}$ & M & M & $\mathrm{H}$ \\
\hline Possible & 3 & $\mathrm{~L}$ & $\mathrm{M}$ & M & $\mathrm{H}$ & $\mathrm{H}$ \\
\hline Likely & 4 & $\mathrm{~L}$ & M & $\mathrm{H}$ & $\mathrm{H}$ & VH \\
\hline Almost Certain & 5 & M & $\mathrm{H}$ & $\mathrm{H}$ & $\mathrm{VH}$ & VH \\
\hline
\end{tabular}

Tabel 5.

Hasil Pemetaan Variabel Risiko 1 pada Matriks Risiko 
Matriks analisa risiko kecelakaan pada item pekerjaan galian dalam kategori Very High tanah dengan risiko alat berat masuk ke lubang galian masuk

Tabel 6.

Hasil Penilaian Risiko Basement

\begin{tabular}{|c|c|c|c|c|c|c|c|}
\hline Item Pekerjaan & Bahaya & Potensi Risiko & $\begin{array}{l}\text { Probability } \\
\text { Index (PI) }\end{array}$ & Rank & $\begin{array}{r}\text { Impact } \\
\text { Index (II) }\end{array}$ & Rank & $\begin{array}{l}\text { Hasil Pemetaan } \\
\text { pada Matriks }\end{array}$ \\
\hline \multirow{4}{*}{ Galian Tanah } & $\begin{array}{l}\text { Material jatuh kedalam } \\
\text { galian }\end{array}$ & $\begin{array}{l}\text { 1a. Pekerja tertimpa } \\
\text { material yang digali }\end{array}$ & $50 \%$ & 3 & $30 \%$ & 2 & M \\
\hline & Tanah & 1b. Pekerja terpeleset & $55 \%$ & 3 & $43 \%$ & 3 & M \\
\hline & $\begin{array}{l}\text { longsor/runtuhnya } \\
\text { dinding samping }\end{array}$ & $\begin{array}{c}\text { 1c. Alat berat } \\
\text { tergelincir ke lubang } \\
\text { galian }\end{array}$ & $90 \%$ & 5 & $88 \%$ & 5 & $\mathrm{VH}$ \\
\hline & $\begin{array}{l}\text { Pengangkatan material } \\
\text { menggunakan Crane }\end{array}$ & $\begin{array}{l}\text { 1d. Pekerja tertimpa } \\
\text { material }\end{array}$ & $43 \%$ & 3 & $58 \%$ & 3 & M \\
\hline \multirow{2}{*}{$\begin{array}{c}\text { Pemasangan } \\
\text { dinding penahan } \\
\text { tanah (soldier } \\
\text { pile) }\end{array}$} & $\begin{array}{l}\text { Alat berat menabrak } \\
\text { fasilitas/pekerja }\end{array}$ & 2a. Pekerja tertabrak & $30 \%$ & 2 & $48 \%$ & 3 & M \\
\hline & $\begin{array}{l}\text { Sling TC putus yang } \\
\text { mengangkat material } \\
\text { berat }\end{array}$ & $\begin{array}{l}\text { 2b. Pekerja tertimpa } \\
\text { material }\end{array}$ & $40 \%$ & 2 & $58 \%$ & 3 & M \\
\hline \multirow{2}{*}{$\begin{array}{l}\text { Pengecoran } \\
\text { soldier pile }\end{array}$} & $\begin{array}{l}\text { Menggunakan concrete } \\
\text { pump }\end{array}$ & $\begin{array}{c}\text { 3a. Pekerja } \\
\text { tersembur mortar }\end{array}$ & $30 \%$ & 2 & $20 \%$ & 1 & $\mathrm{~L}$ \\
\hline & $\begin{array}{l}\text { Penggunaan Agritator } \\
\text { truck }\end{array}$ & $\begin{array}{l}\text { 3b. Pekerja tertabrak } \\
\text { Agritator truck }\end{array}$ & $30 \%$ & 2 & $33 \%$ & 2 & $\mathrm{~L}$ \\
\hline \multirow{2}{*}{$\begin{array}{l}\text { Pondasi Tiang } \\
\text { Pancang }\end{array}$} & $\begin{array}{l}\text { Mengangkat material } \\
\text { berat menggunakan TC }\end{array}$ & $\begin{array}{l}\text { 4a. Pekerja tertimpa } \\
\text { material }\end{array}$ & $33 \%$ & 2 & $45 \%$ & 3 & M \\
\hline & $\begin{array}{l}\text { Kecepatan angin tinggi } \\
\text { saat mobile crane } \\
\text { beroperasi }\end{array}$ & $\begin{array}{l}\text { 4b. Pekerja tertimpa } \\
\text { material }\end{array}$ & $23 \%$ & 2 & $50 \%$ & 3 & M \\
\hline $\begin{array}{l}\text { Pemotongan } \\
\text { pondasi bawah }\end{array}$ & $\begin{array}{l}\text { Pemotongan secara } \\
\text { manual menggunakan } \\
\text { concrete cutter }\end{array}$ & $\begin{array}{c}\text { 5a. Pekerja kejatuhan } \\
\text { potongan material } \\
\text { 5b. Pekerja } \\
\text { tergores/tertusuk besi } \\
\text { beton }\end{array}$ & $40 \%$ & 2 & $40 \%$ & 2 & $\mathrm{~L}$ \\
\hline
\end{tabular}

Tabel 7.

Hasil Penilaian Risiko Lt.1-21

\begin{tabular}{|c|c|c|c|c|c|c|c|}
\hline Item pekerjsan & Bahaya & Potensi Risiko & $\begin{array}{l}\text { Probabilit } \\
\text { y Index (PI) }\end{array}$ & Rank & $\begin{array}{r}\text { Impact } \\
\text { Index (II) }\end{array}$ & Rank & $\begin{array}{c}\text { Hasil } \\
\text { Pemetaan pada } \\
\text { Matriks }\end{array}$ \\
\hline \multirow{4}{*}{$\begin{array}{c}\text { Pekerjaan } \\
\text { struktur Kolom } \\
\text { Lt.1-21 }\end{array}$} & $\begin{array}{l}\text { Mengangkat } \\
\text { material berat } \\
\text { menggunakan } \\
\text { TC }\end{array}$ & $\begin{array}{l}\text { 1a. Pekerja } \\
\text { tertimpa } \\
\text { bekisting }\end{array}$ & $48 \%$ & 3 & $60 \%$ & 3 & M \\
\hline & $\begin{array}{l}\text { Formwork } \\
\text { collapse }\end{array}$ & $\begin{array}{l}\text { 1b. Pekerja } \\
\text { tertimpa } \\
\text { bekisting }\end{array}$ & $50 \%$ & 3 & $60 \%$ & 3 & M \\
\hline & $\begin{array}{l}\text { Perancah tidak } \\
\quad \text { kokoh }\end{array}$ & $\begin{array}{l}\text { 1c. Pekerja } \\
\text { jatuh dari } \\
\text { ketinggian }\end{array}$ & $40 \%$ & 2 & $60 \%$ & 3 & M \\
\hline & $\begin{array}{l}\text { Bekerja di } \\
\text { ketinggian }\end{array}$ & $\begin{array}{l}\text { 1d. Pekerja } \\
\text { jatuh dari } \\
\text { ketinggian }\end{array}$ & $50 \%$ & 3 & $73 \%$ & 4 & $\mathrm{H}$ \\
\hline \multirow{2}{*}{$\begin{array}{c}\text { Pekerjaan } \\
\text { struktur Balok } \\
\text { Lt.1-21 }\end{array}$} & $\begin{array}{l}\text { Bekerja di } \\
\text { ketinggian }\end{array}$ & $\begin{array}{l}\text { 2a. Pekerja } \\
\text { jatuh dari } \\
\text { ketinggian }\end{array}$ & $40 \%$ & 2 & $45 \%$ & 3 & M \\
\hline & $\begin{array}{l}\text { Bekisting kayu } \\
\text { keropos }\end{array}$ & $\begin{array}{l}\text { 2b. Pekerja } \\
\text { terperosok } \\
\text { kebawah }\end{array}$ & $33 \%$ & 2 & $45 \%$ & 3 & M \\
\hline \multirow{2}{*}{$\begin{array}{c}\text { Pekerjaan } \\
\text { struktur Lantai } \\
\text { Lt.1-21 }\end{array}$} & $\begin{array}{l}\text { Bekerja di } \\
\text { ketinggian }\end{array}$ & $\begin{array}{l}\text { 3a. Pekerja } \\
\text { jatuh dari } \\
\text { ketinggian }\end{array}$ & $48 \%$ & 3 & $58 \%$ & 3 & M \\
\hline & $\begin{array}{c}\text { Material } \\
\text { kayu/bekisting } \\
\text { keropos }\end{array}$ & $\begin{array}{l}\text { 3b. Pekerja } \\
\text { terperosok } \\
\text { kebawah }\end{array}$ & $33 \%$ & 2 & $43 \%$ & 3 & M \\
\hline \multirow{4}{*}{ Pengecoran } & $\begin{array}{l}\text { Pembersihan } \\
\text { lokasi } \\
\text { pengecoran } \\
\text { dengan } \\
\text { compressor }\end{array}$ & $\begin{array}{r}\text { 4a. Terkena } \\
\text { paparan debu }\end{array}$ & $40 \%$ & 2 & $33 \%$ & 2 & $\mathrm{~L}$ \\
\hline & $\begin{array}{l}\text { Scaffolding } \\
\text { belum terpasang } \\
\text { dengan benar }\end{array}$ & $\begin{array}{l}\text { 4b. Pekerja } \\
\text { jatuh dari } \\
\text { ketinggian }\end{array}$ & $48 \%$ & 3 & $55 \%$ & 3 & M \\
\hline & $\begin{array}{l}\text { Menggunakan } \\
\text { concrete pump }\end{array}$ & $\begin{array}{c}\text { 4c. Pekerja } \\
\text { tersembur mortar }\end{array}$ & $38 \%$ & 2 & $33 \%$ & 2 & $\mathrm{~L}$ \\
\hline & Pengaruh arus & 4d. Pekerja & $28 \%$ & 2 & $35 \%$ & 2 & $\mathrm{~L}$ \\
\hline
\end{tabular}




\begin{tabular}{|c|c|c|c|c|c|c|c|}
\hline Item pekerjsan & Bahaya & Potensi Risiko & $\begin{array}{r}\text { Probabilit } \\
\text { y Index (PI) }\end{array}$ & Rank & $\begin{array}{r}\text { Impact } \\
\text { Index (II) }\end{array}$ & Rank & $\begin{array}{c}\text { Hasil } \\
\text { Pemetaan pada } \\
\text { Matriks }\end{array}$ \\
\hline & $\begin{array}{l}\text { listrik dari } \\
\text { penggunaan } \\
\text { vibrator }\end{array}$ & $\begin{array}{l}\text { tersengat aliran } \\
\text { listrik }\end{array}$ & & & & & \\
\hline \multirow{5}{*}{$\begin{array}{l}\text { Pekerjaan } \\
\text { MEP }\end{array}$} & $\begin{array}{c}\text { Kabel } \\
\text { mengeluarkan } \\
\text { percikan api }\end{array}$ & $\begin{array}{c}\text { 5a. Pekerja } \\
\text { tersengat listrik }\end{array}$ & $40 \%$ & 2 & $50 \%$ & 3 & M \\
\hline & $\begin{array}{l}\text { Main frame } \\
\text { licin }\end{array}$ & $\begin{array}{l}\text { 5b. Pekerja } \\
\text { terpeleset }\end{array}$ & $48 \%$ & 3 & $38 \%$ & 2 & M \\
\hline & Full body & & & & & & \\
\hline & $\begin{array}{l}\text { harness dan } \\
\text { cross bracett } \\
\text { tidak terpasang } \\
\text { sempurrna }\end{array}$ & $\begin{array}{l}\text { 5c. Pekerja } \\
\text { terjatuh }\end{array}$ & $45 \%$ & 3 & $50 \%$ & 3 & M \\
\hline & $\begin{array}{l}\text { Pengelasan } \\
\text { perpipaan }\end{array}$ & $\begin{array}{l}\text { 5d. Pekerja } \\
\text { terbakar }\end{array}$ & $43 \%$ & 3 & $53 \%$ & 3 & M \\
\hline \multirow{2}{*}{$\begin{array}{l}\text { Pekerjaan } \\
\text { plafond }\end{array}$} & $\begin{array}{l}\text { Perancah tidak } \\
\text { kokoh }\end{array}$ & $\begin{array}{l}\text { 6a. Pekerja } \\
\text { terjatuh }\end{array}$ & $53 \%$ & 3 & $45 \%$ & 3 & M \\
\hline & Kait tidak kuat & $\begin{array}{c}\text { 6b. Pekerja } \\
\text { tertimpa material }\end{array}$ & $48 \%$ & 3 & $40 \%$ & 2 & M \\
\hline \multirow{2}{*}{$\begin{array}{c}\text { Pekerjaan } \\
\text { pasang keramik }\end{array}$} & $\begin{array}{l}\text { Pemotongan } \\
\text { keramik }\end{array}$ & $\begin{array}{r}\text { 7a. Terkena } \\
\text { paparan debu }\end{array}$ & $53 \%$ & 3 & $23 \%$ & 2 & M \\
\hline & $\begin{array}{l}\text { Pecahnya roda } \\
\text { gerinda }\end{array}$ & $\begin{array}{l}\text { 7b. Pekerja } \\
\text { terkena mesin } \\
\text { gerinda } \\
\text { 8a. Pekeria }\end{array}$ & $40 \%$ & 2 & $43 \%$ & 3 & M \\
\hline \multirow{2}{*}{$\begin{array}{c}\text { Pekerjaan } \\
\text { pengecatan } \\
\text { (dinding dan } \\
\text { plafond) }\end{array}$} & $\begin{array}{l}\text { Pengecatan di } \\
\text { ketinggian }\end{array}$ & $\begin{array}{l}\text { menghirup bau } \\
\text { cat yang } \\
\text { menyengat }\end{array}$ & $55 \%$ & 3 & $33 \%$ & 2 & M \\
\hline & $\begin{array}{l}\text { Pengecatan } \\
\text { diluar gedung } \\
\text { menggunakan } \\
\text { gondola }\end{array}$ & $\begin{array}{l}\text { 8b. Pekerja } \\
\text { jatuh dari } \\
\text { ketinggian }\end{array}$ & $75 \%$ & 4 & $83 \%$ & 5 & VH \\
\hline \multirow{2}{*}{$\begin{array}{c}\text { Pemasangan } \\
\text { acp untuk facade }\end{array}$} & $\begin{array}{l}\text { Perancah tidak } \\
\text { kokoh }\end{array}$ & $\begin{array}{l}\text { 9a. Pekerja } \\
\text { jatuh dari } \\
\text { ketinggian }\end{array}$ & $53 \%$ & 3 & $70 \%$ & 4 & $\mathrm{H}$ \\
\hline & $\begin{array}{l}\text { Material acp } \\
\text { terbawa angin } \\
\text { kencang }\end{array}$ & $\begin{array}{c}\text { 9b. Pekerja } \\
\text { tertimpa material }\end{array}$ & $58 \%$ & 3 & $65 \%$ & 4 & $\mathrm{H}$ \\
\hline \multirow{2}{*}{$\begin{array}{c}\text { Pekerjaan } \\
\text { struktur baja } \\
\text { (atap dan } \\
\text { cannopy) }\end{array}$} & $\begin{array}{l}\text { Pengangkatan } \\
\text { konstruksi baja } \\
\text { menggunakan } \\
\text { TC }\end{array}$ & $\begin{array}{c}\text { 10a. Pekerja } \\
\text { tertimpa } \\
\text { konstruksi baja } \\
\text { akibat sling TC } \\
\text { putus }\end{array}$ & $90 \%$ & 5 & $80 \%$ & 4 & VH \\
\hline & $\begin{array}{l}\text { Ketidakstabila } \\
\text { n struktur karena } \\
\text { angin } \\
\end{array}$ & $\begin{array}{l}\text { 10b. Pekerja } \\
\text { jatuh dari } \\
\text { ketinggian }\end{array}$ & $73 \%$ & 4 & $73 \%$ & 4 & $\mathrm{H}$ \\
\hline
\end{tabular}

\section{Identifikasi Faktor Terjadinya Kecelakaan dengan Metode}

\section{Bowtie}

Dari tabel 6 dan tabel 7 tersebut, dapat ditentukan bahwa risiko dominan adalah variabel yang masuk pada kategori $\mathrm{VH}$ (Very High Risk) yang kemudian digambarkan dengan diagram Bowtie [5].

Pembahasan faktor Bowtie pada variabel risiko dominan beserta respon risikonya adalah sebagai berikut.

1. Pekerjaan galian tanah pada basement
a. Risiko
: Alat berat tergelincir ke lubang galian

b. Penyebab :

1. Kondisi fisik operator kurang baik, dengan kontrol:

a. Pemeriksaan kesehatan oleh tim K3

Memiliki Lisensi K3 adalah kartu tanda kewenangan seorang operator untuk mengoperasikan pesawat angkat dan angkut sesuai dengan jenis dan kualifikasinya atau petugas untuk penanganan pesawat angkat dan angkut.

b. Penyediaan APD oleh pihak kontraktor:
Perusahaan wajib menyediakan APD yang dibutuhkan pekerja

c. Pengaturan jadwal kerja yang ideal:

Pengaturan jadwal kerja yang ideal merupakan salah satu faktor yang mempengaruhi efisiensi kerja operator. Produktivitas normal alat berat pada umumnya adalah 8 jam/hari

2. Metode Penggalian, dengan kontrol:

Proteksi galian:

Pemasangan pagar pengaman untuk penggalian:

Pihak kontraktor diwajibkan untuk membuat metode pelaksanaan yang tepat pada saat mengajukan penawaran pekerjaan.

3. Hujan/gerimis, dengan kontrol:

a. Pekerjaan dihentikan selama hujan/gerimis:

Pekerjaan dihentikan sementara karena tanah yang terkena hujan akan mengakibatkan tanah menjadi licin dan mempengaruhi kinerja alat berat

b. Membuat lubang drainase yang cukup: 
Selama pekerjaan penggalian hingga timbunan, kondisi tanah harus dijaga tetap kering dengan

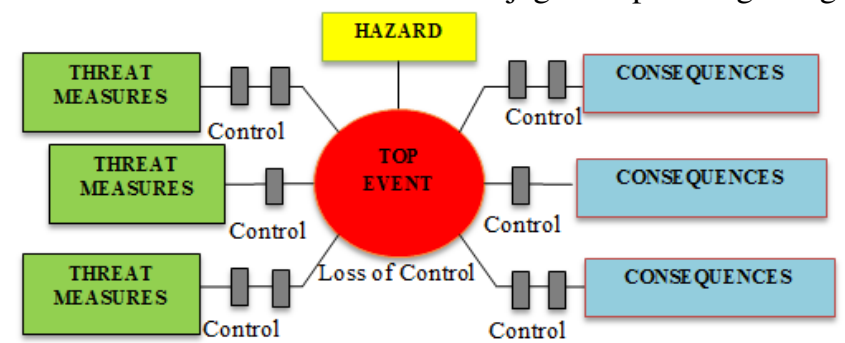

Gambar 2. Diagram Bowtie [6].

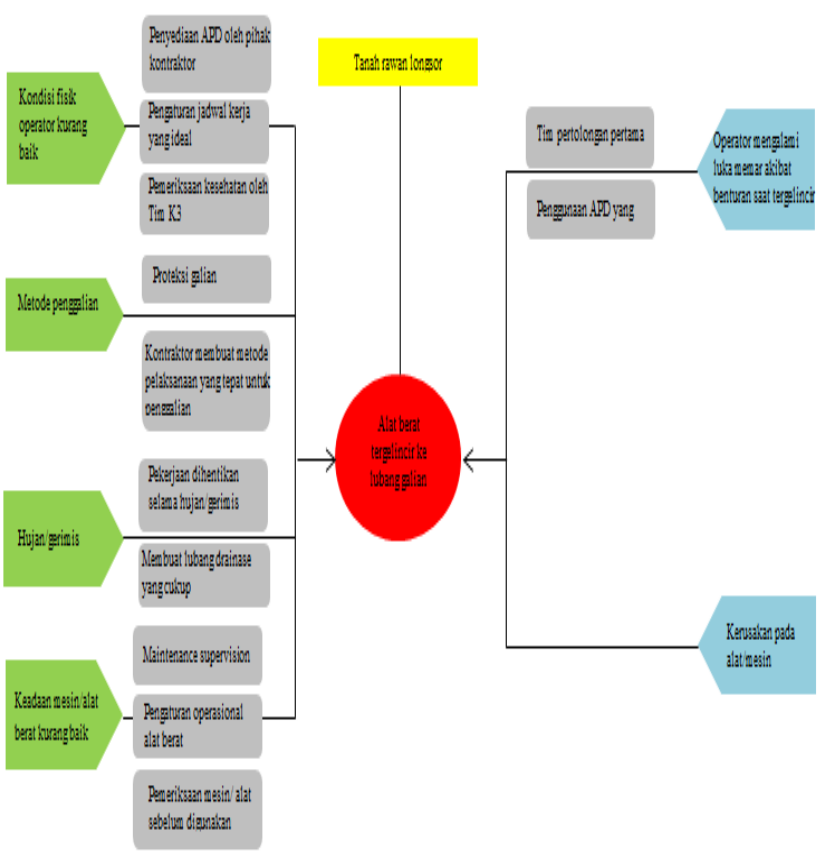

Gambar 3. Diagram Bowtie pada Pekerjaan Galian Tanah pada Basement.

hujan tidak jatuh langsung ke tanah yang dapat mempengaruhi kondisi tanah.

4. Keadaan mesin/alat berat kurang baik, dengan kontrol:

a. Maintenance Supervision:

Melaksanakan pemeliharaan.

b. Pengaturan operasional alat berat:

Kemampuan alat dalam melakukan kegiatan mengeruk, menggusur, mengangkut atau memindahkan tanah dari satu tempat ke tempat lain perlu memperhatikan kapasitas kerja alat yaitu kemampuan kerja satu kali operasi, dan produksi kerja alat yaitu kemampuan kerja dalam satu jam.

c. Pemeriksaan mesin/alat sebelum digunakan:

Perawatan preventif, perawatan berkala, dan perawatan harian

c. Dampak:

Operator mengalami luka memar akibat benturan saat tergelincir, dengan kontrol:

1. Penggunaan APD yang benar:

Operator harus menggunakan APD yang benar seperti Helm, kacamata, sarung tangan, dan sepatu boots, serta respirator untuk pencegahan debu dari kegiatan penggalian terhirup langsung.

2. Tim pertolongan pertama: membuat lubang drainase yang cukup agar air

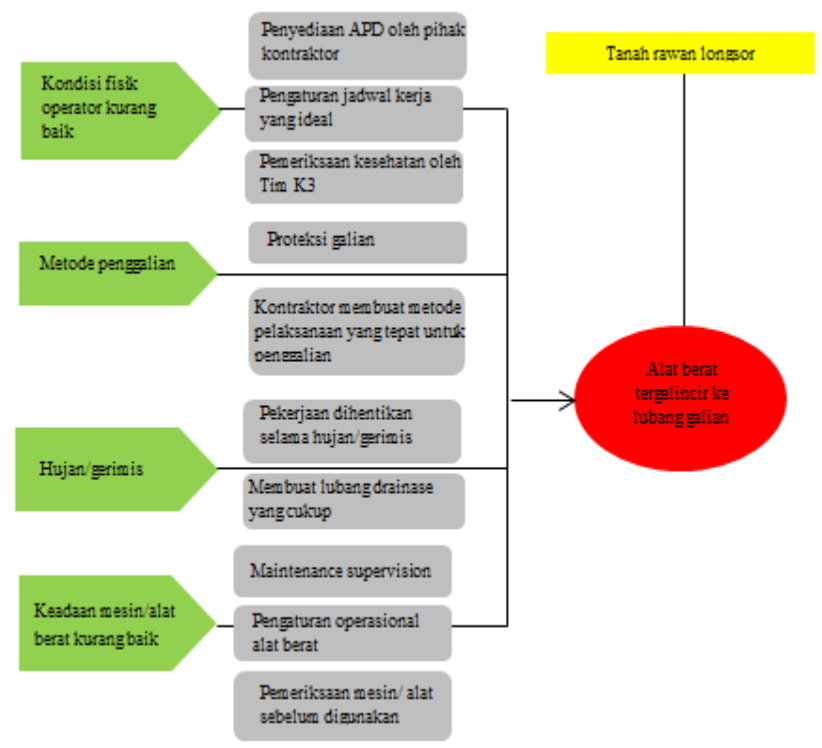

Gambar 4. Diagram Bowtie pada Pekerjaan Galian Tanah pada Basement dengan Penyebab dan Kontrol

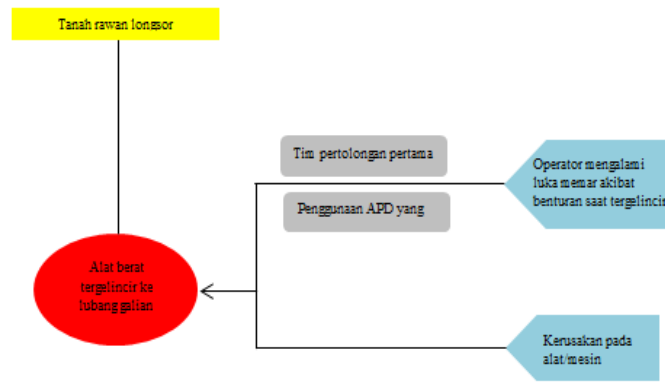

Gambar 5. Diagram Bowtie pada Pekerjaan Galian Tanah pada Basement dengan Dampak dan Kontrol

Pertolongan pertama merupakan tindakan pertolongan yang diberikan terhadap korban dengan tujuan mencegah keadaan bertambah buruk.

d. Faktor Eskalasi pada pekerjaan galian tanah:

Lupa/menolak menggunakan APD, dengan kontrol:

- Kampanye penggunaan APD:

Kampanye ini merupakan bentuk peningkatan kesadaran dan pemahaman karyawan akan pentingnya menggunakan.

2. Pekerjaan pengecatan pada ketinggian

a. Risiko : pekerja jatuh dari ketinggian akibat

sling gondola putus

b. Penyebab :

- Keausan pada kawat sling gondola, dengan kontrol:

Pemeriksaan berkala:

Memeriksa semua bagian gondola secara visual, dan mencatat dalam daftar check list, memeriksa kondisi kompresor secara visual, memeriksa wire sling, penyangga gondola, dan manila rope

- Memberi minyak pelumas pada tali kawat:

Untuk mengurangi gesekan menggosok dari kabel di tali ketika mereka bergerak relatif satu sama lain

- Maintenance Supervision: 


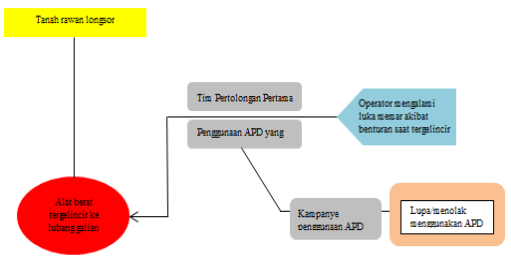

Gambar 6. Diagram Bowtie pada Pekerjaan Galian Tanah pada Basement dengan Faktor Eskalasi dan Kontrol Faktor Eskalasi

Setelah pemakaian gondola selesai, periksa kembali kelengkapan dan keandalan gondola

- Cuaca ekstrem, dengan kontrol:

- Mengetahui informasi kondisi cuaca:

Operator memeriksa kondisi cuaca dan angin di lokasi, Dapat memasang bendera dan mengamati pergerakan bendera tersebut. Untuk cuaca saat hujan, bisa membuat perkiraan kapan hujan akan turun atau bisa minta tolong kepada pihak BMKG.

Pekerjaan dihentikan saat cuaca ekstrem:

Pada saat hujan/gerimis yang disertai angin, harus menunda pekerjaan untuk menghindari risiko kecelakaan kerja

Kondisi kesehatan operator gondola, dengan kontrol:

Penyediaan APD oleh pihak kontraktor

Pemeriksaan kesehatan dan kesiapan sebelum mengoperasikan gondola:

Keberadaan operator yang kompeten akan dapat meminimalkan risiko kecelakaan selama mengoperasikan peralatan-peralatan tersebut.

Metode pengoperasian gondola, dengan kontrol:

Pengarahan mengenai safety oleh tim K3:

Safety talk merupakan salah satu sarana penunjang dalam upaya mencegah terjadinya bahaya di tempat kerja terutama pada High Risk Building

Mengoperasikan sistem gondola sesuai Standard Operating Procedure (SOP)

c.Dampak

Pekerja mengalami kematian akibat jatuh dari ketinggian, Control:

Penggunaan APD yang benar:

Full body harness akan mengikat badan pekerja ke struktur pengaman sehingga menghindarinya jatuh. Helm, lanyard safety harness, sepatu safety, dan kacamata merupakan APD yang wajib dikenakan oleh para pekerja di ketinggian

Tim pertolongan pertama

Menyiapkan ambulans dan rumah sakit terdekat

Gondola mengalami kerusakan akibat jatuh dari ketinggian, dengan kontrol:

Penambahan Safety Rope:

Salah satu pada komponen gondola terdapat 4 buah Wirerope (tali penggantung gondola), yaitu 2 Wirerope utama (Hoist/Motor Gondola) dan 2 Wireropesafety/Safety rope/Blockstop.Safety rope adalah alat pengaman gondola yang berfungsi apabila terjadi penurunan level keranjang ataupun apabila Wirerope utamaputus. Untuk mengendalikan apabila gondola jatuh dari ketinggian, bisa dilakukan penambahan Safety rope yang dikaitkan pada tiang penggantung gondola yang berada di Rooftop

d. Faktor eskalasi pada pekerjaan pengecatan:

- $\quad$ Lupa/menolak menggunakan APD, dengan kontrol:

Kampanye penggunaan APD:

Kampanye ini merupakan bentuk peningkaan kesadaran dan pemahaman karyawan akan pentingnya menggunakan APD seperti Full Body Harness, helm, kacamata.
Tidak adanya penambahan Safety rope, dengan kontrol:Kebijakan Perusahaan:

Penambahan Safety rope, perlu mengidentifikasi masalah utama terlebih dahulu, menyusun alternatif yang akan dipilih dan sampai pada pengambilan keputusan yang terbaik.

3. Pekerjaan struktur atap baja

a. Risiko : pekerja jatuh dari ketinggian akibat sling gondola putus

b. Penyebab: kontrol:

Keausan dan korosi pada kawat sling TC, dengan

- Pengecekan sling sebelum pengoperasian:

Pengecekan sling untuk memastikan sling sebelum digunakan dalam kondisi baik atau tidak rantas

Memberi minyak pelumas pada tali kawat:

Konstruksi yang rumit dan banyaknya beban kerja dibebankan pada wire ropes yang berarti bahwa seperti mesin.

- Cuaca esktrem, dengan kontrol:

Mengetahui informasi kondisi cuaca

Pekerjaan dihentikan saat cuaca ekstrem:

Ketika hujan, penglihatan operator akan terganggu sehingga operator cenderung untuk berhati-hati dalam pengoperasian TC, angin juga sangat berpengaruh pada aktifitas TC.

Kondisi kesehatan operator TC, dengan kontrol:

Pemeriksaan kesehatan dan kesiapan sebelum mengoperasikan TC:

Dalam penerapan SMK3, diperlukan operator-operator TC harus dalam keadaan bugar dan fit, cukup tidur dan tidak dalam mengkonsumsi obat, dilarang minum sesuatu yang beralkohol atau dalam keadaan mabuk.

- Penyediaan APD oleh pihak kontraktor

- Metode pengoperasian TC, dengan kontrol:

- Komunikasi antara mandor dengan operator:

Komunikasi untuk pekerjaan pengangkatan material yang akan dilakukan oleh operator TC harus baik, mana yang lebih penting diangkat didahului

- Mengoperasikan TC sesuai Standard Operating Procedure (SOP)

- Berat beban konstruksi baja, dengan kontrol:

- Menyesuaikan berat beban dengan kapasitas pengangkatan:

Mengetes beban maksimal yang di angkut pada ujung TCuntuk mengetahui seberapa besar berat beban yang dapat diangkat oleh TC.

c. Dampak :

- Pekerja mengalami kematian akibat tertimpa konstruksi atap baja, dengan kontrol:

- Penggunaan APD yang benar:

Pemakaian safety belt untuk menghindari hal-hal yang tidak diinginkan

- Tim pertolongan pertama

- Menyiapkan ambulans dan rumah sakit terdekat:

d. Faktor eskalasi pada pekerjaan struktur atap baja:

- Kurangnya komunikasi, dengan kontrol:

- Briefing sebelum pengoperasian:

Dilakukan briefing sebagai bentuk pengarahan untuk menghindari adanya mis komunikasi pada saat pengoperasian

- Lupa/menolak menggunakan APD dengan kontrol:

Kampanye penggunaan APD:

Menggunakan APD seperti safety belt, sepatu safety, dan kacamata 


\section{KESIMPULAN DAN SARAN}

Risiko dominan terkait kecelakaan kerja pada proyek Spazio Tower II Surabaya berdasarkan The Australia/New Zealand Standard for Risk Management 1999 adalah:

1. Pekerjaan Galian tanah dengan bahaya tanah rawan longsor, dengan risiko alat berat tergelincir ke lubang galian

a. Penyebab: Kondisi fisik operator kurang baik, Metode Penggalian, Hujan/gerimis, Keadaan mesin/alat berat kurang baik

b. Dampak: Operator mengalami luka memar akibat benturan saat tergelincir

c. Faktor eskalasi: Lupa/menolak menggunakan APD

2. Pekerjaan Pengecatan, dengan bahaya pengecatan dinding diluar gedung menggunakan gondola, dengan risiko pekerja jatuh dari ketinggian akibat sling gondola putus

a. Penyebab: Keausan pada kawat sling gondola, Cuaca ekstrem, Kondisi kesehatan operator gondola, Metode pengoperasian gondola

b. Dampak: Pekerja mengalami kematian akibat jatuh dari ketinggian, Gondola mengalami kerusakan akibat jatuh dari ketinggian

c. Faktor eskalasi: Lupa/menolak menggunakan APD, Tidak adanya penambahan Safety rope
3. Pekerjaan Struktur atap baja dengan bahaya pengangkatan konstruksi baja menggunakan TC, dengan risiko pekerja tertimpa konstruksi baja akibat sling putus

a. Penyebab: Keausan dan korosi pada kawat sling TC, Cuaca ekstrem, Kondisi kesehatan operator TC, Metode pengoperasian TC, Berat beban konstruksi baja

b. Dampak: Pekerja mengalami kematian akibat tertimpa konstruksi atap baja, Konstruksi baja rusak akibat sling TC putus

c. Faktor eskalasi: Kurangnya komunikasi, Lupa/menolak penggunaan APD Penyebab, dampak, dan faktor eskalasi disertai dengan kontrol

\section{DAFTAR PUSTAKA}

[1] S. S. Alizadeh and P.Moshashaei, "The Bowtie method in safety management system," Sci. J. Rev., 2015.

[2] The Australian and New Zealand Standard, "AS/NZS 4360:1999," 1999.

[3] Long and et al, "Delay and Cost Overruns in Vietnam Large Construction Project: A Comparison with Other Selected Countries Korean Society of Civil Engineering," J. Civ. Eng., vol. 12, 2008.

[4] I. Al-Hammad, "Criteria for Selecting Construction Labour Market in Saudi Arabia," 2008.

[5] N. Munier, Risk Management for Engineering Projects. Spain: Springer International Publishing Switzerland, 2014. 